UDC 349

\title{
Analysis of Trams' Consumption Depending on the Type of Traffic Light Used
}

\author{
A. Czerepicki ${ }^{1)}$, A. Górka ${ }^{1)}$, J. Szustek ${ }^{2)}$ \\ ${ }^{1)}$ Warsaw University of Technology (Warsaw, Republic of Poland), \\ ${ }^{2)}$ Tramwaje Warszawskie Sp. z o.o. (Warsaw Trams Ltd) (Warsaw, Republic of Poland) \\ (C) Белорусский национальный технический университет, 2019 \\ Belarusian National Technical University, 2019
}

\begin{abstract}
In the XXI century, when environmental awareness is growing and the impact of human activity on the planet is more and more noticeable, striving to minimize energy consumption seems to be a necessary direction in the development of technology. This development cannot take place without an initial understanding and describing the relationships influencing specific technologies. It also needs empirical verification of assumed theories. Modern trams play an important role in the functioning of urban transport. Being one of the oldest modes of environmentally friendly transport, in European capitals they are currently perceived as one of the most convenient means of transport. This is due, among other things, to the high velocity of transport along the route. The energy consumed by trams indirectly depends on the driving characteristics, i. e. speed, acceleration and stops on the route, which are also caused by stopping at traffic light controlled junctions. This paper presents the results of an experiment showing the change in the level of electric energy consumption depending on the applied method of traffic light control. This article presents the conditions influencing the power consumption in trams, describes the possible strategies of traffic lights control and their consequences for other traffic participants. The research was carried out in real conditions in everyday traffic, measuring the level of electricity consumption in case of both fixed-time and actuated signaling with full priority for trams. On the examined section there were both modern asynchronous-drive as well as traditional resistor-drive vehicles. The conclusions drawn from the survey confirm the validity of introducing modern solutions and may be useful for estimating investment costs.
\end{abstract}

Keywords: tram, electricity consumption, traffic lights, tram priority

For citation: Czerepicki A., Górka A., Szustek J. (2019) Analysis of Trams' Consumption Depending on the Type of Traffic Light Used // Science and Technique.18 (6), 490-494. https://doi.org/10.21122/2227-1031-7448-2019-18-6-490-494

\section{Анализ расхода электрической энергии трамваем в зависимости от используемого типа световой сигнализации}

\author{
А. Черепицкий ${ }^{1)}$, А. Гурка ${ }^{1)}$, Я. Шустек ${ }^{2)}$ \\ ${ }^{1)}$ Варшавский технический университет (Варшава, Республика Польша), \\ ${ }^{2)} \mathrm{OOO}$ «Варшавские трамваи» (Варшава, Республика Польша)
}

Реферат. В XXI в., когда растет общественное осознание важности экологических проблем, а результаты деятельности человека на планете носят все более заметный характер, стремление к минимизации расходования энергии представляется единственно правильным и необходимым направлением развития технологий. Это развитие не может осуществляться без предположения и описания зависимостей, влияющих на конкретные технологии, а также без эмпирических исследований, которые данные предположения верифицируют. Современные трамваи как первый вид экологического транспорта сегодня во многих крупных европейских городах считаются одним из наиболее удобных средств передвижения. Причина популярности современного трамвая заключается в скорости его передвижения по выделенным путям. Расход энергии при этом зависит от профиля движения трамвая по трассе, который во многом

\author{
Адрес для переписки \\ Черепицкий Анджей \\ Варшавский технический университет \\ ул. Кошыкова, 75, \\ 00-662, г. Варшава, Республика Польша \\ Тел.: +48 22 234-73-11 \\ aczerepicki@gmail.com
}

\author{
Address for correspondence \\ Czerepicki Andrzej \\ Warsaw University of Technology \\ 75 Koszykowa str, \\ 00-662, Warsaw, Republic of Poland \\ Tel.: +48 22 234-73-11 \\ aczerepicki@gmail.com
}


определяется количеством ускорений, торможений и остановок, в том числе на регулируемых перекрестках. В публикации представлены результаты эксперимента, целью которого был анализ изменения электрической мощности, требующейся трамваю для прохождения трассы, в зависимости от выбранного способа управления световой сигнализацией. Сформулированы условия, которые влияют на величину расхода энергии. Представлены возможные стратегии управления световой сигнализацией на перекрестках с участием трамваев и их последствия для прочих участников движения. Исследования выполнялись в режиме действующей транспортной сети в условиях рабочего дня. Была проведена регистрация количества расхода энергии для разных стратегий управления сигнализацией: с постоянным временем переключения, а также аккомодационной с максимальным приоритетом для трамваев. Исследования касались всех видов трамваев (как современных с асинхронным двигателем, так и с тяговым приводом), которые проследовали по выбранному участку трамвайных путей. Результаты исследований подтверждают обоснованность внедрения современных стратегий управления движением трамвая и могут найти применение в том числе при планировании новых инвестиций в развитие трамвайных маршрутов.

Ключевые слова: трамвай, расход электрической энергии, световая сигнализация, приоритет трамвая

Для цитирования: Черепицкий, А. Анализ расхода электрической энергии трамваем в зависимости от используемого типа световой сигнализации / А. Черепицкий, А. Гурка, Я. Шустек // Наука и техника. 2019. Т. 18, № 6. С. $490-494$. https://doi.org/10.21122/2227-1031-2019-18-6-490-494

\section{Introduction}

In the XXI century, when environmental awareness is growing and the effects of human activity on the planet are more and more perceptible, striving to minimize energy consumption seems to be the only right and necessary direction in the development of technology. Modern trams play an important role in the functioning of urban transport. Being one of the oldest modes of environmentally friendly transport, today in European capitals they are often seen as one of the most convenient means of transport in metropolitan areas.

The highest velocity is achieved by trams on separate tracks, in tunnels or flyovers which do not collide with other infrastructure, so called fast trams. Unfortunately, this is not possible to create fast trams in a dense network of urban buildings, so the element of infrastructure, which is most often used is traffic lights allowing for temporary provision of a protected "tunnel" for the tram. The way of controlling this signaling has a significant impact on the efficiency of public transport.

The energy consumed by trams indirectly depends on the driving characteristics, i. e. speed, acceleration and stops on the route, which may be caused by the need to stop at traffic-light controlled intersections.

The aim of the research presented in this article was to examine the consumption of electricity depending on the type of traffic light control used.

\section{Types of traffic light signaling}

Crossroads controlled by traffic lights can be divided into fix-timed controlled and actuated, which means that they depend on the current traffic conditions. In such control it is possible to give priority to selected groups of participants, which is most often used for public transport. Following the Poznań idea [1], were can adopted three priority levels for trams: full, high and low, and they are distinguished by the criterion of average time loss. A full priority ensures lossless crossing at an intersection, a high priority ensures an average loss of time of up to $10 \mathrm{~s}$ and a low priority applies to other cases above $10 \mathrm{~s}$. Moreover there are limits on the maximum duration of prohibitive signals for non-preferential traffic flows that may cause a short-term reduction in priority level. For this reason, an absolute tram priority similar to that of railways is not introduced, as this would be detrimental to the functioning of the city, causing longterm blockage of intersections without any respect for other road users. In addition, a lack of priority or negative priority can be distinguished, i. e. the deterioration of tram traffic conditions due to design errors - usually a detection deficit or incorrectly accepted coordination offsets.

In Warsaw (the capital of Poland), it was decided to introduce adaptive traffic lights ensuring priority for trams.

The main demonstrated benefit of the priority for trams is the increase in the speed of travel by this means of transport, which reduces the travel costs of passengers and contributes to the increased use of public transport. The experience of Warsaw Trams shows an increase in travel speed by $15-30 \%$ for complex projects covering all intersections over a longer distance. Increasing the speed of the journey goes hand in hand with a reduction in the demand for rolling stock, which results from a reduction in the duration of full tramway brigade cycles. As a result, the same timetable can be achieved with fewer trains. The third benefit of the tram priority is the improvement of safety at junctions by eliminating 
the dilemma zone at entrances with no stops. The standard 3-second length of the yellow signal equivalent of the tram is not sufficient to guarantee safe stopping of the tramway. National regulations do not allow this signal to be extended [2], because such action could increase the risk of rear-end collision of the second train set and cause the dilemma zone phenomenon.

Another benefit of the priority is the impact on electricity consumption. Only the generally mentioned correlation $[3,4]$ has been found in the literature, but no studies carried out in real conditions have been reported. Therefore, it is possible to identify a certain research gap in this field. Additionally, in view of the increasingly frequent arguments concerning the need to increase energy efficiency and decarbonization of transport [5], it seems appropriate to determine the scale of the phenomenon.

Literature contains numerous references to the optimal driving style (theoretical acceleration curve) [6] and simulation tools modelled on railway solutions for determining the energy consumption during the tram ride [7, 4]. However, no studies presenting the scale of occurrence of the phenomenon in uncontrolled conditions have been found.

Obtaining the ideal runs for the electricity consumption postulated in the literature [6] is not achievable - at least until autonomous trams or cabin control systems are introduced, following the model of the ETCS level 3 system used on railways. Where the driver receives information about the speed at which he should go to avoid stopping by means of a cab signaling.

Definitely the most common solution is to give priority to trams in signalling, i. e. to match traffic lights to the smooth passage of the tram, rather than the driving behaviour of the drivers to the displayed signals. The savings achieved in this way can reach up to several percent regardless of the driving style of the driver and without introducing additional, expensive systems.

In Warsaw conditions, the priorities for trams are usually designed as accommodation algorithms, coordinated and open to equipment. The company Warsaw Trams Ltd. in cooperation with the Municipal Roads Administration, runs its own investment and research and development programme. It uses tools for microscopic simulations at the stage of designing and programming drivers and remote monitoring of traffic lights in the post-implementation period. The full priority, ensuring lossless tram passage, operates in Warsaw at 34 intersections, the high priority (average tram loss of less than $10 \mathrm{~s}$ per warehouse) - at 25 intersections, and the low priority (other cases) - at 43 intersections.

The priority in traffic lights affects the level of energy loss by minimizing the likelihood of a tram stopping or braking at a location other than a stop or speed limit. It follows from the above that only tram entries where no stops have been built have an impact on the energy balance. The optimal situation from the energy point of view is to ensure a full priority there. Moreover, shortening the travel time reduces the energy expenditure on the vehicle's own needs, independent of the momentary speed, such as: air-conditioning, air conditioning, ventilation, passenger information displays.

Full priority is achieved by blocking the possibility of simultaneous arrival of the tram and triggering a collision phase (in relation to to tram). Using the local priority, the tram must be detected, and the operation of the control process must be modified in advance of the given formula

$$
t_{w}=t_{P F(T-K)}+t_{\min (K)}+t_{P F(K-T)}+t_{r}+\frac{1}{2} t_{h},
$$

where $t_{P F(T-K)}$ - duration of the phase-to-phase transition leading to the collision phase; $t_{\min (K)}-$ minimum duration of the collision phase; $t_{P F(K-T)}-\mathrm{du}-$ ration of the phase-to-phase transition until tram groups are switched on; $t_{r}$ - driver response time; $t_{h}$ - braking time.

Energy losses occur as tram traffic increases. Since collision phase blocking is limited by the maximum acceptable duration of prohibitive signals for non-priority streams, there may be several a number of trams without reserves in the signaling cycle. The second source of loss, which should be considered as a design error, is the lack of sufficiently distant detection, especially when the tram has to trigger a signal.

The issue of energy losses can also be considered for the passive preference of trams in the coordinated traffic lights, not necessarily accommodative. The priority for trams in coordination requires that the width of the coordination beams in the signaling cycle be maximized. These beams are time windows within which the tram can smoothly and without wasting time through successive intersections. The wider the beam, the lower the level of time loss for trams, but to minimize energy loss it is also necessary to eliminate the cases of prematurely giving a permit signal for trams before the start of the coordination beam.

There are some similarities here to the coordination of signaling for vehicles. There are few works in which the conditions for integrated tram- 
vehicle coordination were described, such as the works of M. Kaczmarek [8]. Automation of computational processes in this area is practically unavailable at present. The results obtained based on the Transyt method available on the market [9], tested on the example of one of the designed tram routes, turned out to be unsatisfactory, so at present it is not possible to give up the "manual" work performed by the designer in this area.

\section{Research method}

A series of 8 crossroads on a 2600 -metre section of Marymoncka Street, where full priority was applied, was selected as a testing ground. The level of the road is mostly flat with the exception of the crossroad with Zabłocińska Street, which is located in a hollow.

The street has a profile of $2 \times 2$ lanes with extensions at the entrance and a fully separated track on the eastern side of the road. It conducts individual traffic of the intensity of 1000-1100 PCE (Passenger Car Equivalent) in each direction in each direction. Two tram lines with numbers 6 and 17 running parallel to each other make 10 departures per hour in each direction except for the peak and 15 in the peak. Priority is given to trams at local level over and above coordination plans, which have been optimized for individual vehicle traffic in the absence of effective tram-vehicle coordination. The obtained priority for trams is full and provides a travel speed of $25.9 \mathrm{~km} / \mathrm{h}$ in rush hour. Disturbances to the coordination beams due to the vehicle priority are minor and cover about $20 \%$ of the cycles.

Giving priority to trams takes place at the local level over coordination plans, which have been optimized for vehicular traffic only. In the analyzed section tramcars with asynchronous drive type $120 \mathrm{Na}$ (Pesa Swing) and 20-metre $134 \mathrm{~N}$ (Pesa Jazz) operate as well as with resistor-drive types $(23.2 \%)$.

The experiment consisted in temporarily switching off all active tram privileges and switching to fix-time control according to emergency programs with 80 -second cycle. Since the coordination of signaling did not consider the preferences of trams, such signaling working conditions reflected a situation in which a tram accidentally gains or loses out on an individual traffic-oriented signaling system.

The study was carried out on a weekday from 11:00 a. m. to 8:00 p. m., so that both the inter-peak period and the afternoon peak were measured. The obtained results were compared to identical periods of the day from two other days when the weather conditions were analogous.
In none of the days were unusual situations or traffic stoppages on the surveyed section recorded.

Data acquisition was carried out basically with the use of energy consumption recorders installed in the traction substation supplying the section of Marymoncka Street. The data were aggregated in 15-minute intervals. Supplementary measurements were carried out by means of recorders installed in trams type $134 \mathrm{~N}$.

Energy consumption for traction purposes depends not only on fixed elements such as: route profile, inter-stop distances and location of stops, maximum speed, but also on vehicle load and start-up method $[10,11]$. However, because the measurements were carried out in real conditions (different drivers and constantly changing vehicle filling), it was assumed that the total differences in these parameters are small and have negligibly little influence on the results of the experiment.

\section{Results}

The obtained results unequivocally indicate a significant relationship between the allocation of full priority in traffic lights and electricity consumption, which is illustrated by the diagram of accumulated hourly electricity consumption given in $\mathrm{kW} \cdot \mathrm{h}$ (Fig. 1). The continuous line in the graph shows the energy consumption on the day of priority switch-off. During the entire period of priority shutdown, i. e. $10 \mathrm{~h}$, an increase in power consumption of $340 \mathrm{~kW} \cdot \mathrm{h}$ compared to the average consumption in the corresponding period on the remaining days was recorded, which represents an increase in energy consumption of $13.5 \%$ over the entire period under investigation. The increase in the number of passing trams has a strong impact on energy consumption, but the relationship between these parameters is not unknown. The Pearson correlation coefficient was 0.68 .

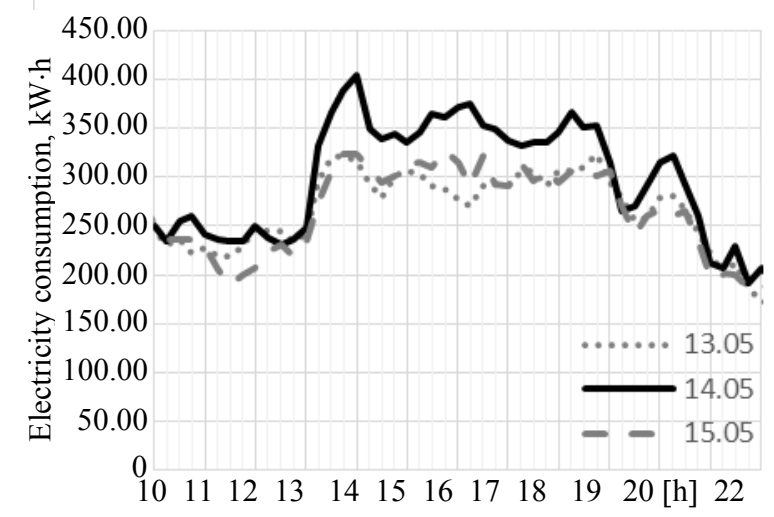

Fig. 1. Cumulative hourly electricity consumption for three consecutive days 
The greatest deviation from the average values was recorded during the departure of additional brigades from the depot around 14:00, the peak of the afternoon peak and the exits to the depot after 20:00. It could be assumed that the relationship between the impact of the local priority on electricity consumption and the intensity of tram traffic on the route exists, but is not linear.

The increase in energy consumption can also be seen from the level of a single vehicle. The speed run shows additional stoppages before traffic lights and two stoppages and the energy consumed during this time. Data from the recorder in the vehicle indicate that the tram during one run in the tested sequence consumed about $2 \mathrm{~kW} \cdot \mathrm{h}$ of energy more than in the case of similar runs during the operation of the full priority. It should be remembered, however, that some of the energy consumed during braking is transferred to the network, and its amount is difficult to estimate. This energy can only be consumed on an ongoing basis if there is a second vehicle on the network that can receive it, otherwise it "escapes into the air". According to the manufacturer's data, recuperation covers up to $30 \%$ of the energy consumed for braking.

However, regardless of the number of stoppages or brakes, in individual cases data from substations show real values and generalized to one-hour periods, so they also contains the energy taken from the recuperation instead of the network.

\section{CONCLUSIONS}

Although the pilot experiment did not cover the whole day, the analysis clearly showed that there is a close and important link between the full priority for traffic lights and the energy consumption of the tramway. The reading of the total energy consumption of trams in the form of traction substation showed an increase of $13.5 \%$, what means approximately 40 euro gross for the analyzed section (within 10 hours of measurement). By estimating energy consumption for the whole year - by introducing full priority in traffic lights on the tested track annually - the Company saves approximately 15600 euro only from energy used to drive vehicles. In addition, it should be remembered that including the priority also means shorter tram journey times, i. e. shorter time of consuming the remaining $25 \%$ of energy used for own needs (heating, air conditioning, displays). The experiment should be repeated by modifying it in such a way as to determine the relationship between the low and medium priority and energy consumption. In addition, consideration should be given to whether it is justified to omitted parameters such as driving style, type of rolling stock or vehicle filling. The relationship between the impact of a local priority on electricity consumption and tram traffic volume on the route exists but is not linear. In order to verify the thesis and find other factors, more detailed studies should be carried out and an attempt should be made to link the variables with each other and the way of control at the crossroads.

\section{REFERENCES}

1. Rychlewski J. (2010) Experience from the Application of the Tram Priority in Poznań. Transportation Overview Przeglad Komunikacyjny, (4-6), 42-47 (in Polish).

2. Rozporządzenie Ministra Infrastruktury w Sprawie Szczegółowych Warunków Technicznych dla Znaków i Sygnałów Drogowych Oraz Urządzeń Bezpieczeństwa Ruchu Drogowego i Warunków ich Umieszczania na Drogach (Dz. U. 220 poz. 2181 z 2003 r.) (in Polish).

3. Krych A. (2009) Efficient Acceleration of Tram Transport with Priority Control. Polish ITS Congress (CD).

4. Szeląg A., Gorczyca P. (2006) Energy Consumption of Trams in Dynamic Priority Systems. TTS Technika Transportu Szynowego, (5), 41-44 (in Polish).

5. European Commission (2011) White Paper. Roadmap to a Single European Transport Area-Towards a Competitive and Resource Efficient Transport System. Available at: $\mathrm{https} / / /$ ec.europa.eu/transport/themes/strategies/2011_ white paper_en.

6. Chyła K., Rawicki S., Urbański M. (2017) Coordination of Tramway Journeys to Minimise Energy Consumption. Napędyi Sterowanie, (7/8), 134-139 (in Polish).

7. Rawicki S., Nowak M. (2016) Energy-Saving Coordination of Traffic of Some Trams Driven by Induction Motors. Poznan University of Technology Academic Journals: Electrical Engineering, (85), 447-457.

8. Kaczmarek M. (2011) Integrated Coordination of Trams and Private Vehicles in Transport Corridors. Materiaty VIII Konferencja Naukowo-Techniczna z Cyklu "Problemy Komunikacyjne Miast w Warunkach Zattoczenia Motoryzacyjnego" pt. "Nowoczesny Transport Publiczny w Obszarach Zurbanizowanych" [Materials of the VIII Scientific and Technical Conference from the Series "Communication Problems of Cities in the Conditions of Automotive Congestion" Part "Modern Public Transport in Urban areas"]. Poznań, Stowarzyszenie Inżynierów i Techników Komunikacji Rzeczpospolitej Polskiej (in Polish).

9. Transyt TRL Software. Available at: https://trlsoftware. com/products/junction-signal-design/transyt/ (Accessed 25 May 2019).

10. Czuchra W., Prusak J., Zając W. (2006) Asynchronous Trams - Energy Efficiency Assessment. TTS Technika Transportu Szynowego, (1-2), 66-72 (in Polish).

11. Kuminek T. (2013) Energy Consumption in Tram Transport. Logistics and Transport, 2 (18), 93-100.

Received: 08.10.2019

Accepted: 29.11.2019

Published online: 06.12.2019 